\title{
SURVEY PERILAKU PENANGGULANGAN UPAYA PENCEGAHAN COVID-19 PADA TATANAN KELUARGA PADA MAHASISWA KEPERAWATAN DAN KEBIDANAN
}

\author{
Elisabeth Surbakti ${ }^{*}, 1$, Dame Evalina Simangunsong ${ }^{2}$, Nurlina Tarigan ${ }^{3}$ \\ ${ }^{I}$ Poltekkes Kemenkes Medan Jurusan Kebidanan Medan \\ ${ }^{2}$ Poltekkes Kemenkes Medan Jurusan Keperawatan Medan \\ ${ }^{3}$ Dinas Kesehatan Kabupaten Samosir \\ e-mail: 1elisabethsurbakti@gmail.com,2dameevalinas@yahoo.com,3nurlinatrg52@gmail.com \\ *Email: elisabethsurbakti@gmail.com (Coresponden)
}

\begin{abstract}
Corona virus (SARS-cov-2), is a disease called Coronavirus disease 2019 (Covid-19). The behavior of the community towards the prevention of Covid-19 is still low, which is thought to play a role in the increase in cases from time to time. The role of the community is urgently needed to suppress the transmission of Covid-19. The general public, in this case the D-three students of Midwifery and Nursing at the Medan Ministry of Health Poltekkes, need to disseminate information on the transmission of Covid-19. Surveys on student behavior can play a role in socializing the prevention of Covid-19 transmission. This study aims to determine the description of student behavior towards the prevention of Covid-19 transmission in the family setting. The research method with a survey, identifies the characteristics of the D-three Nursing and Midwifery students and their behavior (knowledge, attitudes and actions) towards the prevention of Covid-19 in the family setting. Data collection from March to May 2020. The population is D-three students in Midwifery and Nursing with a total of 595 respondents. The research procedure was carried out by collecting data through google forms such as student characteristics (gender, age, ethnicity, place of residence, level/class), behavior (knowledge, attitudes and actions) regarding overcoming Covid-19 prevention efforts in the family setting. The results of the study: $97.6 \%$ of the information regarding the prevention of Covid-19 transmission, the general source of information was through social media, $85.8 \%, 68.1 \%$ of respondents with good knowledge, $79.4 \%$ strongly agree, do prevention $68.9 \%$, and in the family setting the attitude of the family strongly agrees $69.6 \%$. There needs to be further learning for students about infectious disease pandemics in the community, especially the prevention of Covid19 transmission in the family and community settings.
\end{abstract}

Keywords: Covid-19; Behavior;Countermeasures;Prevention; Family-Order

\begin{abstract}
ABSTRAK
Corona virus (SARS-cov-2), merupakan penyakit disebut dengan Coronavirus disease 2019 (Covid-19). Perilaku masyarakat terhadap penanggulangan upaya pencegahan Covid-19 masih rendah yang diduga berperan dalam peningkatan kasus dari waktu ke waktu. Peran masyarakat sangat dibutuhkan untuk menekan penularan Covid-19. Masyarakat awam dalam hal ini mahasiswa D-tiga Kebidanan dan Keperawatan Poltekkes Kemenkes Medan membutuhkan sosialisasi informasi penularan Covid-19. Survey terhadap perilaku mahasiswa dapat berperan untuk melakukan sosialisasi pencegahan penularan Covid-19. Penelitian ini bertujuan untuk mengetahui gambaran perilaku mahasiswa terhadap penanggulangan upaya pencegahan penularan Covid-19 pada tatanan keluarga. Metode penelitian dengan survey, mengidentifikasi karakteristik mahasiswa D-tiga Keperawatan dan Kebidanan serta perilaku (pengetahuan, sikap dan tindakan) terhadap penanggulangan upaya pencegahan Covid-19 pada tatanan keluarga. Pengumpulan data pada bulan Maret sampai Mei 2020. Populasi adalah mahasiswa D-tiga Kebidanan dan Keperawatan dengan jumlah 595 responden. Prosedur penelitian dilakukan pengumpulan data melalui google form seperti karakteristik mahasiswa (jenis kelamin, usia, suku, tempat tinggal, tingkat/kelas), Perilaku (pengetahuan, sikap dan tindakan) tentang penanggulangan upaya pencegahan Covid-19 pada tatanan keluarga. Hasil penelitian : belum pernah mengetahui informasi tentang penanggulangan upaya pencegahan penularan Covid-19 sejumlah 97,6\%, sumber informasi umumnya melalui media sosial 85,8\%, responden berpengetahuan baik $68,1 \%$, mempunyai sikap sangat setuju $79,4 \%$, tindakan melakukan pencegahan $68,9 \%$, dan dalam tatanan keluarga sikap keluarga sangat setuju 69,6\%. Perlu adanya pembelajaran lanjutan kepada mahasiswa tentang pandemic penyakit menular di komunitas khususnya penanggulangan upaya pencegahan penularan Covid19 pada tatanan keluarga dan masyarakat
\end{abstract}


Vol. 16 No. 3 September - Desember 2021

Kata kunci: Covid-19; Perilaku;Penanggulangan; Pencegahan; Tatanan-Keluarga

\section{PENDAHULUAN}

Corona virus jenis baru (SARS-cov-2) dan penyakitnya disebut Coronavirus disease 2019 (Covid-19), berasal dari Wuhan, Tiongkok, ditemukan pada akhir Desember tahun 2019. Sampai saat ini sudah dipastikan terdapat 181 negara yang sudah terserang Covid hingga 15 April 2020. Covid-19 telah menginfeksi lebih dari 2,7 juta orang, meninggal 191.899 dan sembuh 757.427 di seluruh dunia hingga Jumat (24/4/2020) pukul 09.30 WIB, menurut data yang dihimpun Universitas Johns Hopkins (https://tirto.id/eT1Z, Univ Johns Hopkins).

Dilihat dari tingkat kematian akibat virus tersebut CFR (Case Fatality Rate) CFR COVID19 lebih rendah dibandingkan dengan CFR SARS, yaitu sebesar 2\% sedangkan SARS mencapai $10 \%$. Walaupun CFR lebih rendah tetapi kasus Covid-19 berkembang dengan cepat. Atas kejadian tersebut, WHO sebagai Badan Kesehatan Dunia menilai risiko akibat virus tersebut termasuk kategori tinggi di tingkat global dan menetapkan status Public Health Emergency of International Concern (PHEIC) sejak tanggal 30 Januari $2020^{1}{ }^{2}$

Virus ini secara genetik sangat berbeda dari virus SARS-CoV dan MERS-CoV. Penelitian saat ini menunjukkan bahwa homologi antara Covid19 dan MERS-CoV memiliki karakteristik DNA coronavirus pada kelelawar-SARS yaitu dengan kemiripan lebih dari $85 \%$. Ketika dikultur pada vitro, Covid-19 dapat ditemukan dalam sel epitel pernapasan manusia setelah 96 jam. Coronavirus merupakan keluarga besar virus yang menyebabkan penyakit pada manusia dan hewan. Pada manusia biasanya menyebabkan penyakit infeksi saluran pernapasan, mulai flu biasa hingga penyakit yang serius seperti Middle East Respiratory Syndrome (MERS) dan Sindrom Pernapasan Akut Berat/ Severe Acute Respiratory Syndrome (SARS). Penyakit ini terutama menyebar di antara orang- orang melalui tetesan pernapasan dari batuk dan bersin (2019-nCoV).

Indonesia telah mengeluarkan status darurat bencana terhitung mulai tanggal 29 Februari 2020 hingga 29 Mei 2020 terkait pandemi virus ini dengan jumlah waktu 91 hari $^{3}$. Sosialisasi gerakan social distancing dilakukan sebagai langkah untuk dapat mengendalikan pertambahan kasus Covid-19, yang bermakna bahwa untuk dapat mengurangi bahkan memutus mata rantai infeksi
Covid-19 seseorang harus menjaga jarak aman dengan manusia lainnya minimal 2 meter, dan tidak melakukan kontak langsung dengan orang lain, menghindari pertemuan massal ${ }^{4}$.

Sampai saat ini belum ada vaksin yang dapat digunakan untuk mencegah terjadinya infeksi Covid-19. Para ilmuwan terus mengembangkan vaksin untuk virus tersebut,

bahkan jika wabah sudah berakhir. Oleh sebab itu, upaya pengendalian yang dapat dilakukan dalam waktu singkat adalah melakukan kesiapsiagaan. Langkah kesiapsiagaan yang dilakukan tidak lepas dari prinsip penanggulangan wabah, yaitu pada fase pencegahan, fase deteksi, dan fase respons.

Fase pencegahan ini meliputi pembuatan pedoman kesiapsiagaan yang mengacu pada UU Kekarantinaan Kesehatan dan UU Wabah Penyakit Menular sehingga mendukung implementasi tata kelola global penanganan wabah; menyampaikan surat edaran mengenai kesiapsiagaan pencegahan Covid-19 kepada Dinas Kesehatan Provinsi/Kabupaten/Kota, Kantor Kesehatan Pelabuhan, dan seluruh rumah sakit. Mengadakan Posko pencegahan Covid-19, meningkatkan Komunikasi, Edukasi dan Informasi (KIE) terkait virus tersebut agar tidak menimbulkan kepanikan di tengah masyarakat akibat terpapar informasi yang tidak benar, membangun paradigma positif antar pemangku kepentingan dan proaktif dalam membangun kesadaran publik sehingga ikut bergerak dalam upaya antisipasi penyebaran Covid-19.

Pada fase ini peran individu, keluarga dan masyarakat juga penting, setelah memahami bagaimana penularan dapat terjadi kepada individu, maka hal ini dapat menjadi acuan untuk melakukan sosialisasi terhadap upaya penanggulangan pencegahan penularan virus tersebut. Upaya yang dapat dilakukan antara lain: menggunakan masker apabila sedang mengalami gejala batuk dan pilek; segera mendatangi fasilitas pelayanan kesehatan jika ada keluhan lebih lanjut; menerapkan perilaku hidup bersih dan sehat; memasak daging dan telur sampai matang; berhati-hati saat kontak dengan hewan terutama hewan liar; serta menghindari kontak dengan orang yang menunjukkan gejala penyakit pernapasan ${ }^{2}$.

Media seperti Gerakan Keluarga Jaga Kesehatan Mandiri (Gergaji), Penggunaan Sabun 
dan Handsanitizer, Yuk di Rumah Saja, Menjaga Jarak (Social Distancing) yang telah dikeluarkan oleh team Promkes Kemenkes RI diharapkan mampu dipahami oleh masyarakat dalam melakukan upaya penanggulangan saat ini. Namun, harapan tidak semudah yang kita harapkan, kasus penularan Covid-19 terus bertambah, hingga saat ini sudah mencapai angka 8882 kasus positif, 1107 sembuh dan 743 meninggal dunia (Satgas Covid-19, update tanggal 26 April 2020).

Perilaku masyarakat yang masih rendah terhadap penanggulangan upaya pencegahan Covid-19 diduga berperan dalam peningkatan kasus tersebut. Peran masyarakat sangat dibutuhkan guna menekan penularan Covid-19. Masyarakat awam yang jauh dari informasi kesehatan membutuhkan sosialisasi informasi penularan Covid-19. Survey terhadap perilaku seorang mahasiswa yang di didik untuk menjadi seorang pelayan kesehatan diharapkan juga dapat berperan untuk melakukan sosialisasi pencegahan ini, pada masyarakat secara umum dan keluarga secara khusus. Perilaku pencegahan yang tepat pada tatanan keluarga dan diharapkan dapat menjadi model pada keluarga yang lain dan masyarakat sekitarnya ${ }^{5}$

Poltekkes Kemenkes Medan, sebagai institusi pendidikan kesehatan vokasi turut mengambil bagian dalam upaya penanggulangan pencegahan penularan Covid-19 dengan memberlakukan WFH (Work From Home) bagi mahasiswa dan dosen serta tenaga pendidikan sejak 19 Maret 2020 hingga saat ini. Dari uraian latar belakang di atas peneliti tertarik ingin melakukan penelitian survey tentang perilaku upaya penanggulangan pencegahan penularan Covid-19 pada mahasiswa (D3 Keperawatan dan D3 Kebidanan) yang lebih banyak berinteraksi dengan individu dan masyarakat dalam melakukan asuhan keperawatan dan kebidanan dan juga mendapatkan mata kuliah Ilmu Kesehatan Masyarakat.

Peneliti ingin melihat bagaimana gambaran mahasiswa tersebut sebagai bagian dari cikal bakal pelayan kesehatan yang telah dibekali pelajaran epidemiologi dalam ilmu kesehatan masyarakat turut berperan dalam penanggulangan upaya pencegahan penularan Covid-19 pada tatanan keluarga.
Adapun tujuan penelitian adalah untuk mengetahui gambaran perilaku mahasiswa terhadap penanggulangan upaya pencegahan penulatan Covid-19 pada tatanan keluarga dengan mengidentifikasi karakteristik mahasiswa, pengetahuan, sikap dan tindakan mahasiswa tentang penanggulangan upaya pencegahan penularan Covid-19 pada tatanan keluarga.

Hasil penelitian diharapkan bermanfaat capaian pembelajaran (CP) ketrampilan khusus tentang pandemic penyakit menular di komunitas dan meningkatkan ketrampilan mahasiswa D3 Keperawatan dan Kebidanan dalam upaya penanggulangan pencegahan epidemik dan pandemik penyakit menular.

\section{METODE}

Jenis penelitian adalah survey dengan mengidentifikasi karakteristik mahasiswa D3 Keperawatan dan D3 Kebidanan serta perilaku (pengetahuan, sikap dan tindakan) penanggulangan upaya pencegahan Covid-19 pada tatanan keluarga.

Penelitian ini dilakukan di Medan dengan menggunakan aplikasi Google Form yang akan dikirim melalui whatshap group. Penelitian ini berlangsung selama masa work from home (WFH) yang telah dimulai sejak 19 Maret 2020-29 Mei 2020.

Populasi dalam penelitian ini adalah seluruh mahasiswa Program Studi D3 Jurusan Keperawatan Medan dan D3 Jurusan Kebidanan Medan (yang berjumlah 595 responden (total populasi)

Pengumpulan data dilakukan untuk memperoleh informasi yang dibutuhkan dalam rangka mencapai tujuan penelitian.Hal ini berkaitan dengan bagaimana cara mengumpulkan data, siapa sumbernya dan alat yang digunakan.

Jenis sumber data adalah data primer, seperti karakteristik mahasiswa (jenis kelamin, usia, suku, tempat tinggal, tingkat/kelas), Perilaku (pengetahuan, sikap dan tindakan) tentang penanggulangan upaya pencegahan Covid-19 pada tatanan keluarga mahasiswa tersebut.

Prosedur Pengumpulan Data, diawali dengan persiapan sarana dan prasarana yang mendukung seperti izin penelitian dari Poltekkes Kemenkes Medan. Penelitian berlangsung pada masa WFH hingga 29 Mei 2019.

Pengolahan data, yang telah terkumpul selanjutnya akan diolah cara mengentry data ke 
dalam perangkat lunak computer yakni SPSS (Statistical Product and Service Solutions).

Instrumen penelitian atau pengumpulan data dapat diuraikan: lembaran checklist biodata responden (jenis kelamin, usia, suku, tempat tinggal, tingkat/kelas). Instrumen pengetahuan, sikap dan tindakan penanggulangan upaya pencegahan Covid-19 pada tatanan keluarga.

Data yang telah dikumpulkan dianalisis untuk mendeskripsikan semua variable yang diteliti dengan analisis univariat

Analisis tiap variable disajikan dalam bentuk grafik dan distribusi frekuensi, rerata dan standar deviasi. Variabel yang dianalisis adalah karakteristik responden, perilaku tentang penanggulangan upaya pencegahan penularan Covid-19.

\section{HASIL}

Gambaran umum lokasi penelitian, Propinsi Sumatera Utara pada awalnya banyak institusi Akademi Kesehatan baik dari Depkes, Pemda, TNI/POLRI dan Swasta. Institusi pendidikan dibawah naungan Depkes ada 9 (sembilan) yaitu: 1.Akademi Keperawatan di Medan, 2.Akademi Gizi di Lubuk Pakam, 3.Akademi Kesehatan Lingkungan di Kabanjahe, 4.Akademi Kebidanan di Medan,5.Akademi Kebidanan di Pematang Siantar, 6.Akademi Kebidanan di Padang Sidimpuan, 7.Akademi Farmasi di Medan, 8.Akademi Kesehatan Gigi di Medan, 9.Akademi Analis Kesehatan di Medan.

Akademi Keperawatan di Medan berdiri pada tahun 1995 dengan nama Pendidikan Ahli Madya (PAM) Keperawatan Medan, dan pada tahun 1999 melembaga menjadi Akademi Keperawatan.

Akademi Kebidanan Medan berawal dari Sekolah Bidan yang didirikan pada tahun 1954, kemudian berubah menjadi Sekolah Juru Kesehatan tahun 1968 dan berubah menjadi Sekolah Pengatur Rawat A (SPRA). Pada tahun 1975 berubah menjadi Sekolah Perawat Kesehatan (SPK), tahun 1998 dikonversi menjadi Akademi Kebidanan Depkes RI Medan. Pendirian Politeknik Kesehatan didasarkan pada PP NO. 60 tahun 1999, selanjutnya terbit SK. Menkes No. 298/SK/Menkes/2001 yang merupakan wujud kebijakan pemerintah dalam meningkatkan efektifitas penggunaan sumber daya dan sumber dana yang tersedia yang bertujuan untuk efisiensi, maka dibentuklah Politeknik Kesehatan.

Pada Bulan Oktober dan Novemebr 2001, semua Akademi Kesehatan yang bernaung di bawah Depkes menyikapi SK tersebut dan segera membentuk Panitia Ad Hock yang terdiri dari 5 orang perwakilan dosen setiap Akademi. 3 orang dari Kanwil Depkes Propinsi Sumatera Utara dan dari Pusdiknakes 1 orang sesuai petunjuk yang ada. Panitia Ad Hock bertugas mempersiapkan pembentukan Poltekkes mulai dari penyiapan dan pelaksanaan proses pemilihan Direktur dan Pembantu Direktur, Ketua Jurusan dan Sekretaris Jurusan, Ketua Prodram Studi dan Sekretaris Program Studi. Proses pemilihan berjalan terus dan terlaksana secara demokratis. Dengan pelantikan Direktur Poltekkes maka meleburlah seluruh Struktur Organisasi Akademi tersebut diatas mengikuti Struktur Organisasi Poltekkes. Kemudian dilanjutkan pemilihan Pembantu Direktur I, II dan III, Ketua Jurusan/Prodi dan Sekjur/Prodi. Penunjukkan personil di Direktorat dan perangkat yang ada di Jurusan/Prodi. Akhirnya pada tanggal 20 Juni 2002 dilaksanakan pelantikan Pudir, Kajur/Prodi dan Sekjur/Prodi oleh Direktur Poltekkes Medan. Dengan bergabungnya Akademi-Akademi Kesehatan menjadi Poltekkes maka aturan dan mekanisame kerja Akademi berubah mengikuti Struktur Organisasi Poltekkes. Tata laksana kerja Poltekkes pada awalnya mengacu pada SK Menkes No. 298 tahun 2001 dan selanjutnya disempurnakan dengan SK Menkes No. OT.01.01.2.4.0375 tahun 2003. Struktur Organisasi Politeknik Kesehatan Depkes Medan di tahun mendatang akan mengacu kepada Permenkes No. 890/Menkes/Per/VIII/2007 tanggal 2 Agustus 2007.

Program studi DIII kebidanan dan Keperawatan merupakan pendidikan tinggi yang diharapkan memegang posisi terdepan, dan menjadi pelopor pembaharuan serta rujukan dalam disiplin ilmu Kebidanan dan Keperawatan yang menghasilkan Ahli Madya Kebidanan dan Keperawatan, yang dapat berkontribusi dalam meningkatkan derajat kesehatan nasional. Program Studi D III Kebidanan dan Keperawatan senantiasa berpegang teguh kepada nilai-nilai kebenaran hakiki dan universal, keilmuan, kebebasan mimbar dan kebebasan akademik; keadilan, demokrasi, hak asasi manusia, taat hukum, menghargai kemajemukan dan kemitraan, edukatif, ilmiah, dan religius

Mahasiswa merupakan komponen penting pada Program Studi D III Kebidanan dan Keperawatan. Mahasiswa diharapkan dapat mengembangkan diri dan mandiri dalam mengambil keputusan akademik secara profesional, kreatif, inovatif dan antisipatif. 
Mahasiswa diharapkan untuk selalu berpartisipasi dalam berbagai kegiatan akademik maupun kegiatan kemahasiswaan. Pembinaan mahasiswa dilakukan melalui program pendidikan kepemimpinan mahasiswa sebagai kader intelektual bangsa, program pengembangan bakat, minat dan nalar mahasiswa serta pembinaan organisasi mahasiswa sesuai dengan dinamika perubahan nasional dan regional

Program studi DIII Kebidanan dan Keperawatan senantiasa berupaya untuk memberdayakan sumber daya yang bermutu tinggi dalam rangka memberikan kontribusi terhadap peningkatan daya saing bangsa. Mahasiswa dipacu untuk mampu mengembangkan kapabilitas intelektual dan emosional sehingga dapat menjadi warga Negara yang bertanggung jawab dan mampu bersaing digelanggang kehidupan dengan memenuhi kriteria akuntabilitas publik.

Prodi DIII Kebidanan beralamat di Jl. Jamin Ginting No.13,5, Lau Cih, Kec. Medan Tuntungan, Kota Medan, Sumatera Utara 20137 dan Prodi D III keperawatan Beralamat di jalan Bunga Ncole No.95 Kelurahan Kemenangan Tani Kecamatan Medan Tuntungan Sumatera Utara.

Distribusi Frekuensi Responden Berdasarkan Jurusan

\begin{tabular}{|l|l|}
\hline & Distribusi Responden Penelitian \\
& $\begin{array}{l}\text { Jurusan } \\
\text { Keperawatan } \\
\text { Jurusan } \\
\text { Kebidanan } \\
\text { Medan }\end{array}$ \\
\hline
\end{tabular}

Responden pada penelitian ini adalah mahasiswa jurusan Keperawatan ada sebayak $64,8 \%$ dan Jurusan Kebidanan ada sebanyak 35,2\%.

Distribusi Responden berdasarkan suku

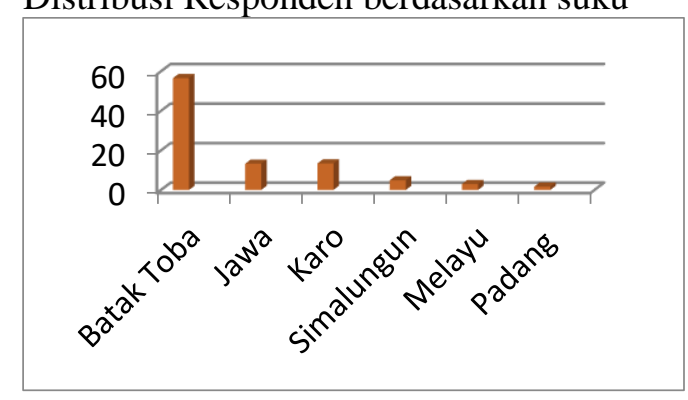

Responden pada penelitian ini pada umumnya batak toba, diikuti derngan suku Jawa dan Karo.
Distribusi Responden berdasarkan tempat tinggal selama WFH

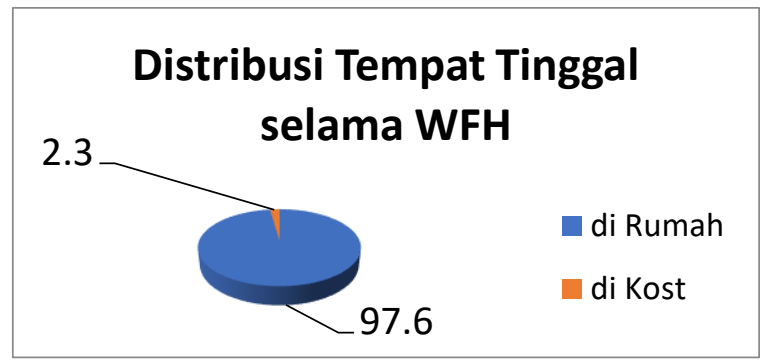

Responden pada penelitian ini pada umumnya tinggal bersama orang tua $97,6 \%$, hanya $2,3 \%$ yang masih tetap tinggal di kost.

Distribusi Frekuensi Informasi Tentang Penaggulangan Upaya Pencegahan Penularan COVID 19

Informasi Tentang Penaggulangan Upaya Pencegahan Penularan COVID 19

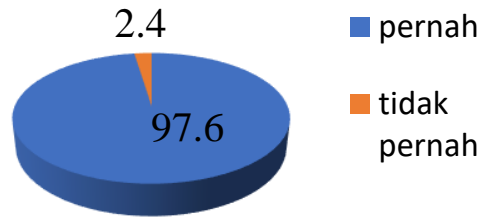

Responden pada penelitian ini pada umumnya Informasi Tentang Penaggulangan Upaya Pencegahan Penularan COVID 19 belum pernah $97,6 \%$ hanya $2,4 \%$ saja yang sudah pernah.

Distribusi Frekuensi Sumber Informasi Tentang Penaggulangan Upaya Pencegahan Penularan Covid-19

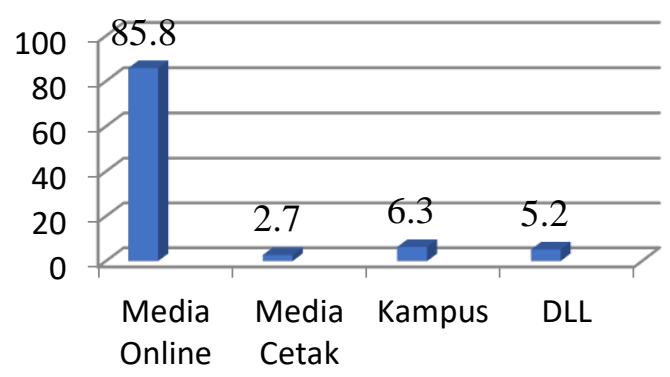

Responden pada penelitian ini pada umumnya Sumber Informasi Tentang Penaggulangan Upaya Pencegahan Penularan Covid-19, melalui media sosial sebanyak $85,8 \%$, sedangkan kampus hanya $6,3 \%$ dan media cetak hanya $2,7 \%$ 


\section{Aspek Perilaku Responden}

Distribusi pengetahuan responden tentang Covid19 dan upaya memutus rantai penularan

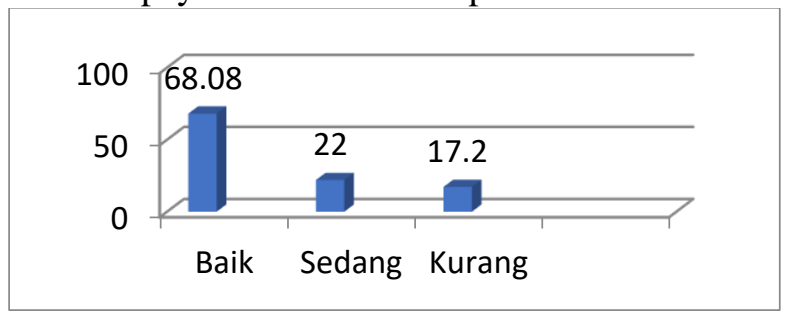

Responden pada penelitian ini pada umumnya mempunyai pengetahuan responden tentang Covid-19 dan upaya memutus rantai penularan, baik $68,08 \%$, sedang $22 \%$ tetapi masih ada pengetahuan kurang $17,2 \%$.

\section{Distribusi sikap responden tentang upaya memutus rantai penularan Covid-19}

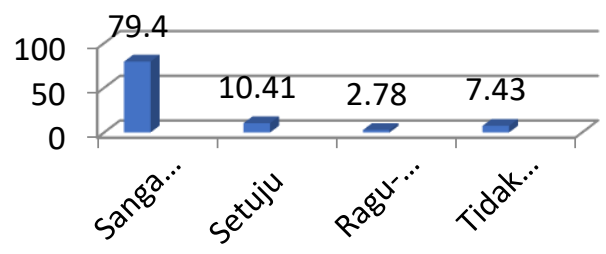

Responden pada penelitian ini pada umumnya mempunyai sikap responden tentang upaya memutus rantai penularan Covid-19, sangat setuju $79,4 \%$ setuju $10,41 \%$ tetapi ada tidak setuju $7,43 \%$

Distribusi Tindakan responden tentang upaya memutus rantai penularan Covid-19

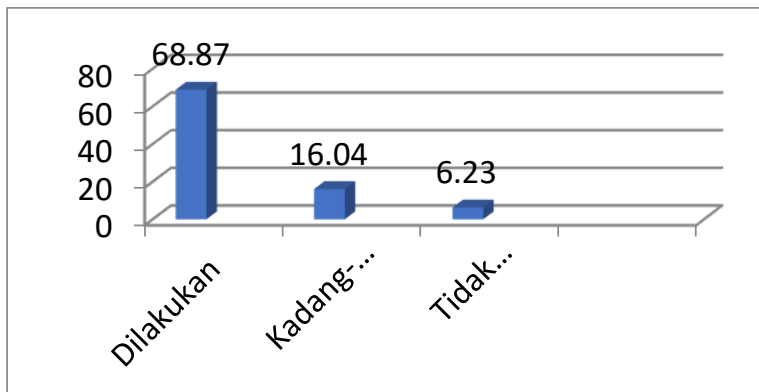

Responden pada penelitian ini pada umumnya mempunyai Tindakan responden tentang upaya memutus rantai penularan Covid-19 dilakukan $68,87 \%$, kadang kadang $16,04 \%$ tetapi ada yang tidak dilakukan sebanyak $6,23 \%$.

Distribusi Sikap Keluarga responden tentang upaya memutus rantai penularan Covid-19

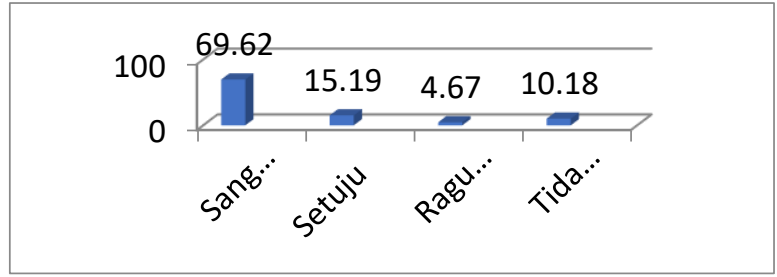

Responden pada penelitian ini pada umumnya mempunyai Sikap Keluarga responden tentang upaya memutus rantai penularan Covid-19 sangat setuju $69,62 \%$, setuju $15,19 \%$, ragu ragu $4,67 \%$ tetapi ada tidak setuju sebanyak 10,18\%

\section{PEMBAHASAN}

\section{Karakteristik Responden}

Responden pada penelitian ini, mahasiswa Jurusan Keperawatan ada 64,8\% dan Jurusan Kebidanan $35,2 \%$, pada umumnya suku batak Toba, diikuti dengan suku Jawa dan Karo. Responden pada penelitian selama kegiatan WFH tinggal bersama orang tua $97,6 \%$, hanya $2,3 \%$ yang masih tetap tinggal di kost. Upaya pemerintah dalam menggerakkan dan mencanangkan kampus merdeka dan WFH-SFH ${ }^{6}$ (Nadiem Anwar Makarim, 2020a) adalah upaya untuk mengurangi dan mengatasi penyebaran Covid-19 di dalam kampus dan tempat pendidikan yang mempunyai potensi yang besar untuk dapat menimbulkan penularan yang luar biasa, yang dapat dilakukan untuk penanggulangan dan upaya dalam meminimalisir dan mengurangi dampak yang terjadi akibat pandemi Covid-19 pada mahasiswa dengan tinggal dirumah orang tua dibandingkan dengan tinggal ditempat kost ${ }^{7}$

Sumber informasi dalam menyebarkan informasi tentang Penanggulangan Upaya Pencegahan Penularan Covid-19 dapat melalui media cetak maupun media elektronik. Sumber Informasi yang diperoleh tentang Penaggulangan Upaya Pencegahan Penularan Covid-19, melalui media sosial $85,8 \%$, kampus hanya $6,3 \%$ dan media cetak hanya $2,7 \%$. Hal ini dapat saja terjadi karena umumnya zaman milenieal dengan menggunakan berbagai informasi dari media elektronik khususnya media sosial. Media cetak maupun elektronik, telah menyumbangkan informasi terkait dengan upaya pencegahan penularan Covid-19 ${ }^{8}$

\section{Aspek Perilaku Responden \\ Pengetahuan}

Pengetahuan yang baik dapat membuat responden untuk melakukan pencegahan dan 
pemutusan rantai penularan Covid-19, yang didukung dengan penelitian Anggraeni 2018, ada hubungan yang signifikan antara pengetahuan keluarga dengan penerapan hidup bersih dan sehat. Pengetahuan responden tentang Covid-19 dan upaya memutus rantai penularan, umumnya baik $68,08 \%$, kategori sedang $22 \%$ tetapi masih ada pengetahuan kurang 17,2\%.Penularan atau pemutusan mata rantai Covid-19 dapat dilakukan juga dengan PHBS dimana dengan hidup bersih penularan dapat dicegah

Pengetahuan sangat penting dapat memproses terbentuknya tindakan seseorang. Seseorang harus tahu terlebih dahulu arti dan manfaat perilaku bagi dirinya, khususnya dalam upaya pemutusan rantai penularan Covid-19 kemudian seseorang akan mengadopsi perilaku baru. Perilaku yang didasari pengetahuan akan semakin tinggi upaya pemutusan rantai penularan Covid-19.

Tingkat pengetahuan seseorang juga dipengaruhi pendidikan. Mahasiswa dibangku kuliah mungkin akan lebih mudah memahami sesuatu dalam hal ini pencegahan Covid-19. Selain pendidikan, pengetahuan juga dapat dipengaruhi oleh pengalaman yang pernah dialami masa lalu, kebudayaan lingkungan sekitar dan media massa yang memberikan kemudahan seseorang untuk memperoleh pengetahuan yang baru.(8). Pengetahuan tentang covid-19 ini sangat penting dimiliki oleh masyarakat sehingga masyarakat mampu untuk mengambil keputusan dalam berperilaku yang tepat dalam rangka memutus rantai penularan covid 19. . Adapun cakupan pengetahuan yang diukur kepada responden tentang penyakit corona virus-19 yaitu : penyebab, tanda-tanda orang yang menderita penyakit Covid-19, penularan penyakit Covid-19, cara mencuci tangan yang benar agar terhindar dari penularan, manfaat menggunakan masker, manfaat penerapan sosial distancing/physical distancing pada penularan covid 19 .

Penelitian lain yang sejalan dengan hasil penelitian ini adalah penelitian yang dilakukan oleh Clements JM $(2020)^{10}$ yang menunjukan bahwa masyarakat Amerika Serikat memiliki pengetahuan dan perilaku yang baik dan Zhonng BL $(2020)^{11}$ yang meneliti pada masyarakat Chinase sebagai tempat awal ditemukannya Virus corona ini juga memiliki pengetahuan dan perilaku yang baik dan positif . Hal ini juga dihubungkan dengan pengalaman masyarakat China menghadapi wabah SARS pada Tahun 2000. Pengetahuan masyarakat tentang Covid-19 merupakan aspek yang sangat penting dalam masa pandemic seperti sekarang ini, yang meliputi penyebab covid, karakteristik virusnya, tanda dan gejala, istilah yang terkait dengan covid, pemeriksaan yang diperlukan dan proses transmisi serta upaya pencegahan penyakit tersebut ${ }^{12}$

\section{Sikap}

Upaya memutus rantai penularan Covid-19 umumnya responden mempunyai sikap sangat setuju $79,4 \%$, setuju $10,4 \%$ tetapi ada tidak setuju $7,4 \%$. Hasil penelitian ini menujukkan bahwa sikap responden tentang upaya memutus rantai penularan Covid-19 umumnya sangat setuju $79,4 \%$ artinya sudah sangat mempunyai sikap baik pada responden. Walaupun masih di awal kejadian covid tetapi sikap untuk mencegah sudah baik, bahkan sudah lebih mempunyai sikap yang positif.

Pendidikan tinggi juga sangat berperan untuk membuat sikap seseorang menjadi lebih baik. Walau masih ada beberapa sikap yang kurang yaitu $7,5 \%$. Sikap yang kurang setuju perlu kembali dilakukan pemberitahuan informasi yang berhubungan dengan upaya memutus rantai penularan Covid-19.

Hal ini sesuai dengan pendapat Azwar (2007), ${ }^{13}$ bahwa salah satu faktor yang dapat mempengaruhi pembentukan sikap seseorang yaitu orang lain yang dianggap penting. Seseorang akan cenderung memiliki sikap yang konformis atau searah dengan orang yang dianggap penting.10. Peningkatan sikap positif pada responden dapat dipengaruhi oleh pengetahuan yang meningkat dan menjadikan responden dapat berubah sikap, hal ini di karenakan sikap responden yang menerima dan merespon pemberian pendidikan kesehatan dengan baik.Didukung oleh penelitian yang dilakukan oleh Andarini dan Purnamasari $(2012)^{14}$ bahwa remaja yang memiliki informasi yang benar cenderung memiliki sikap dan tingkah laku yang bertanggung jawab dapat dilihat dari penurunan yaitu yang tidak setuju hanya $7,4 \%$.

Sarwono (2011) $)^{15}$ menyatakan sikap dibentuk melalui proses belajar sosial di mana individu memperoleh informasi dari orang lain.Salah satu faktor yang berhubungan signifikan perilaku adalah sikap. Sikap dapat menimbulkan cara berpikir tertentu dalam masyarakat dan cara berpikir ini mempengaruhi tindakan untuk membuat keputusan.12. Mubarak dalam Fitriani $(2011)^{16}$ menyatakan bahwa dalam 
merubah sikap dapat dilakukan pembinaan melalui pendidikan kesehatan.13

Sikap responden yang perlu diketahui seperti upaya pencegahan penularan Covid 19, Pembatasan Sosial Berskala Besar (PSBB), Setiap anggota keluarga mempunyai kewajiban mendukung upaya pencegahan penularan covid 19 (di rumah saja, rajin cuci tangan, pakai masker, jauhi kerumunan), Mengatur menu sehat dan seimbang, konsumsi sayuran dan buah, berolahraga, berjemur pada pagi hari, Mengatur menu sehat dan seimbang, konsumsi sayuran dan buah, berolahraga, berjemur pada pagi hari, sangat perlu diinformasikan pada anggota keluarga, berpartisipasi dengan petugas kesehatan setempat untuk melaporkan bila ada ODP dan PDP dalam keluarga.

\section{Tindakan}

Upaya memutus rantai penularan Covid-19, responden pada umumnya mempunyai tindakan untuk melakukan upaya memutus rantai penularan Covid-19 sebanyak 68,9\%, dan masih ada yang tidak dilakukan sebanyak $6,2 \%$. Tindakan yang baik dalam melakukan upaya pencegahan.

Masyarakat sangat disarankan untuk tinggal di rumah saja, harus menggunakan masker, pekerja/karyawan bekerja dari rumah (Work From Home/WFH), selalu mencuci tangan dan menerapkan PHBS. PHBS merupakan starategi yang dapat mencegah penyebaran Covod-19. Masyarakat terus dihimbau untuk meningkatkan prilaku hidup bersih dan sehat dalam upaya pencegahan penyebaran Covid-19, karena perilaku masyarakat sangat berperan penting dalam penurunan angka penyebaran Covid-19.

Tindakan yang dilakukan antara lain : Anggota keluarga menerapkan cuci tangan dengan air mengalir dengan menggunakan sabun, bila keluar dari rumah, menggunakan masker, melakukan aktifitas di dalam rumah, anggota keluarga berjemur di panas matahari sebelum pukul 10 pagi, keluarga melakukan senam/olahraga di dalam rumah, keluarga mengkonsumsi suplemen vitamin setiap hari, banyak mengkonsumsi buah dan sayuran, berupaya menjaga kebersihan rumah dan pekarangan, menerapkan pola makan dan istirahat yang teratur, melakukan penyemprotan cairan desinfektan di sekeliling dan di dalam rumah

\section{Sikap Keluarga}

Sikap memiliki tiga komponen pokok yaitu kepercayaan atau keyakinan, ide dan konsep terhadap suatu objek, kehidupan emosional atau evaluasi terhadap suatu objek, dan kecenderungan untuk bertindak. Pada penelitian ini Sikap keluarga dalam upaya memutus rantai penularan Covid-19, umumnya responden mempunyai sikap sangat setuju $69,6 \%$, setuju $15,19 \%$, ragu-ragu $4,67 \%$ tetapi ada tidak setuju sebanyak $10,2 \%$ tentang upaya memutus rantai penularan Covid19 pada keluarga. Keluarga merupakan kelompok sosial yang pertama dalam kehidupan manusia, tempat pertama dalam belajar dan menyatakan diri sebagai manusia sosial di dalam hubungan interaksi dengan kelompoknya. Pengaruh dominan orang tua terhadap anak terlihat dalam hal distorsi terhadap waktu penjadwalan kegiatan pembelajaran peserta didik, baik secara struktur, pembagian tugas dan internalisasi norma-norma. Peran yang selama ini dilaksanakan di satuan pendidikan beralih fungsi di satuan keluarga. Disinilah dibutuhkan peran orang tua agar anak memiliki self-regulating sehingga mampu mengajarkan dirinya dalam upaya memberikan penguatan secara internal pada dirinya.

Keluarga merupakan kelompok sosial yang pertama dalam kehidupan manusia, tempat pertama dalam belajar dan menyatakan diri sebagai manusia sosial di dalam hubungan interaksi dengan kelompoknya. Disinilah peran orang tua menjadi penting, bagaimana mensikapi pelaksanaan kebijakan pendidikan pada masa waktu peserta didik dalam hal ini mahasiswa belajar di rumah (study from home) tetapi tetap memperhatikan pencegahan penularan covid-19 ${ }^{17}$

Sikap adalah respon tertutup seseorang terhadap stimulus atau objek tertentu yang sudah melibatkan faktor pendapat dan emosi bersangkutan (senang tidak senang, setuju-tidak setuju, baik- tidak baik dan sebagainya). Dalam menentukan sikap yang utuh, pengetahuan, pikiran, keyakinan, dan emosi memegang peranan penting. Oleh karena itu perubahan sikap responden tentang pencegahan penularan covid 19 dalam tatanan keluarga adalah baik.

Peran orang tua sangat dibutuhkan agar anak memiliki self-regulating sehingga mampu mengajarkan dirinya dalam upaya memberikan penguatan secara internal pada dirinya. Pendekatan strategi ini tentu saja dapat diimplementasikan secara gradual bergantung situasi proses pembelajaran yang diasumsikan terhadap sikap keluarga, misalnya mengkondisikan lingkungan perilaku hidup 
bersih, belajar dimulai dengan adanya perubahan perilaku, memberikan stimulus dan respon menjadi yang esensial, menciptakan terbentuknya contiguity, dan adanya kesamaan prinsip dalam pencegahan terjadinya penularan Covid-19 dalam tatanan keluarga. Kesadaran orang tua dan anaknya dalam hal ini mahasiswa Keperawatan dan Kebidanan harus diwujudkan dalam pembinaan kehidupan keluarga yang utuh ${ }^{18}$

Peran orang tua sangat dibutuhkan agar anak memiliki self-regulating sehingga mampu mengajarkan dirinya dalam upaya memberikan penguatan secara internal pada dirinya $a^{18}$.

Sikap keluarga dalam upaya penanggulangan pencegahan penularan Covid19, angota keluarga wajib menjaga kesehatan. Sebaiknya anggota keluarga atau tetangga yang sudah menderita Covid-19, dapat menerima keberadaannya dan mau mengisolasikan diri. Keluarga dan seluruh anggota keluarga wajib melapor ke pusat layanan kesehatan terdekat bila ada gejala yang menyerupai gejala penyakit Covid 19. Keluarga wajib menyiapkan dan mengkonsumsi makanan bergizi untuk mendukung kesehatan fisik keluarga. Selama upaya penanggulangan pencegahan penularan Covid-19 berlangsung, kegiatan pembelajaran bagi anggota keluarga yg sekolah dan kuliah tetap berjalan. Walaupun social distancing masih diberlakukan, keluarga harus memperhatikan pertumbuhan dan perkembangan anak supaya tetap sehat dan cerdas. Usaha sampingan dibutuhkan untuk menambah pendapatan keluarga selama masa penanggulangan upaya pencegahan penularan COvid-19.

\section{KESIMPULAN}

Berdasarkan hasil penelitian yang telah dilakukan, kesimpulan sebagai berikut:

1. Karakteristik mahasiswa d3 Keperawatan ada 64,8\% dan d3 Kebidanan 35,2\%, umumnya suku batak toba, diikuti derngan suku jawa dan karo, serta tinggal bersama orang tua $97,6 \%$, dan hanya $2,3 \%$ yang tinggal di kost.

2. Informasi tentang penanggulangan upaya pencegahan penularan covid 19 belum pernah $97,6 \%$ hanya $2,4 \%$ yang sudah pernah dan sumber informasi umumnya melalui media sosial $85,8 \%$, kampus $6,3 \%$ dan media cetak hanya $2,7 \%$

3. Pengetahuan responden tentang penanggulangan upaya pencegahan penularan Covid-19 pada tatanan keluarga, berpengetahuan baik $68,1 \%$, dan masih ada pengetahuan kurang $17,2 \%$.

4. Sikap responden tentang penanggulangan upaya pencegahan penulatan covid-19 pada tatanan keluarga, sangat setuju 79,4\% setuju $10,4 \%$ tetapi ada tidak setuju $7,4 \%$

5. Tindakan responden tentang penanggulangan upaya pencegahan penularan covid-19 pada tatanan keluarga, dilakukan 68,9 \%, kadang kadang 16,0\% tetapi ada yang tidak dilakukan $6,2 \%$.

6. Sikap keluarga responden tentang upaya memutus rantai penularan covid-19 sangat setuju $69,6 \%$, setuju $15,2 \%$, ragu ragu $4,7 \%$ tetapi ada tidak setuju $10,2 \%$

Disarankan perlu adanya pembelajaran lanjutan kepada mahasiswa tentang pandemic penyakit menular di komunitas khususnya penanggulangan pencegahan penulatan Covid-19 pada tatanan keluarga. Perlu adanya penelitian lanjutan tentang penanggulangan upaya pencegahan penularan Covid-19 pada tatanan keluarga dan masyarakat

\section{UCAPAN TERIMA KASIH}

Ucapan terima kasih kepada Direktur Poltekkes Kemenkes Medan, Ketua Jurusan Kebidanan dan Keperawatan Medan, mahasiswa Jurusan Kebidanan dan Keperawatan atas bantuan dan dukungannya hingga selesainya penelitian ini.

\section{DAFTAR PUSTAKA}

1. Prati C, Pelliccioni GA, Sambri V, Chersoni S, Gandolfi MG. COVID-19: Its Impact On Dental Schools In Italy, Clinical Problems In Endodontic Therapy And General Considerations. Int Endod J. 2020;53(5):723.

2. Kemenkes RI 2020. Corona Virus Disease 2019. Peratur Menteri Kesehat Republik Indones. 2020.

3. Koesmawardhani NW. Pemerintah Tetapkan Masa Darurat Bencana Corona Hingga 29 Mei 2020. Detiknews Diunduh Dari Https//News Detik Com/Berita/D4942327/Pemerintah- 
Tetapkan-Masa-Darurat-BencanaCorona-Hingga-29-Mei-2020. 2020.

4. Wang S-Y, Wang O, Zhang R, Owens A, Efros AA. CNN-Generated Images Are Surprisingly Easy To Spot... For Now. In: Proceedings Of The IEEE/CVF Conference On Computer Vision And Pattern Recognition. ; 2020:8695-8704.

5. Buana DR. Analisis Perilaku Masyarakat Indonesia Dalam Menghadapi Pandemi Virus Corona (Covid-19) Dan Kiat Menjaga Kesejahteraan Jiwa. Salam J Sos Dan Budaya Syar-I. 2020;7(3):217226.

6. Makarim N. Personal Branding Nadiem Anwar Makarim Melalui Pidato Hari Guru 1Devy Putri Kussanti, 2Murtiadi. $J$ Trias Polit. 2020;4(1):51-65.

7. Sumantyo FDS. Pendidikan Tinggi Di Masa Dan Pasca Covid-19. J Kaji Ilm. 2020;1(1):81-92.

8. Nurmansyah MI, Al-Aufa B, Amran Y. Peran Keluarga, Masyarakat Dan Media Sebagai Sumber Informasi Kesehatan Reproduksi Pada Mahasiswa. Indones J Reprod Heal. 2013;3(1):16-23.

9. Purnamasari I, Raharyani AE. Tingkat Pengetahuan Dan Perilaku Masyarakat Kabupaten Wonosobo Tentang Covid19. J Ilm Kesehat. 2020;10(1):33-42.

10. Clements JM. Knowledge And Behaviors Toward COVID-19 Among US Residents During The Early Days Of The Pandemic: Cross-Sectional Online Questionnaire. JMIR Public Heal Surveill. 2020;6(2):E19161.

11. Zhong B-L, Luo W, Li H-M, Et Al. Knowledge, Attitudes, And Practices Towards COVID-19 Among Chinese Residents During The Rapid Rise Period Of The COVID-19 Outbreak: A Quick Online Cross-Sectional Survey. Int J Biol Sci. 2020;16(10):1745.

12. Hidayah N. Perilaku Hidup Bersih Sehat Pada Tatanan Rumah Tangga Di Dusun Cung Belut, Desa Semen Kecamatan Paron Kabupaten Ngawi. War Bhakti Husada Mulia J Kesehat. 2019;6(1).
13. Azwar S. Kualitas Tes Potensi Akademik Versi 07A. J Penelit Dan Eval Pendidik. 2008;12(2).

14. Arosna AD, Widodo A, Kep A, Kep KS. Pengaruh Pendidikan Kesehatan Reproduksi Terhadap Pengetahuan Dan Sikap Mahasiswa Di FIK-UMS. 2014.

15. Sarwono SW. Psikologi Remaja. 2011.

16. Khotimah M. Hubungan Antara Dukungan Keluarga Dan Peran Petugas Kesehatan Dengan Kepatuhan Minum Obat Kusta. Unnes J Public Heal. 2014;3(2).

17. Notoatmodjo S. Ilmu Perilaku Kesehatan. 2010.

18. Habibi A. Normal Baru Pasca Covid-19. ADALAH. 2020;4(1). 